DOI: $10.1515 / \mathrm{adms}-2015-0023$

\author{
K. Borůvková ${ }^{1,2^{*}}$, T. Bakalova ${ }^{2}$, L. Voleský ${ }^{2}$, P. Louda ${ }^{2}$ \\ ${ }^{1}$ Technical University of Liberec, Faculty of textile engineering, Studentská 2, 46117 Liberec, \\ Czech Rep. \\ ${ }^{2}$ Technical University of Liberec, Inst. for Nanomaterials, Advanced Technology and \\ Innovation, Studentská 2, 46117 Liberec, Czech Rep. \\ *karolina.boruvkova@tul.cz
}

\title{
THE INFLUENCE OF NANOADDITIVES ON THE BIOLOGICAL PROPERTIES AND CHEMICAL COMPOSITION OF PROCESS FLUIDS
}

\begin{abstract}
In this study process fluids were tested after the addition of nanoparticles. Cooling and lubricating process fluids are used in machining to reduce wear on tools, to increase machine performance and to improve product quality. The use of process fluids leads to their pollution and contamination. Nanoparticles were added to the process fluids in order to increase their antibacterial activity. The selected nanoparticles were nanoparticles of metallic silver. The process fluids were modified by the addition of silver nitrate and ascorbic acid. Reduction of silver nanoparticles in the volume of the fluid was achieved using UV. The modified fluids were tested for their cytotoxicity and changes in chemical composition. The cytotoxicity of process fluids was tested for the purpose of verifying whether the process fluids, which are in direct contact with the skin of the operator, affect the health of the operator. The cytotoxicity of the process fluids was tested on human fibroblast cells. Fibroblasts are the basic cells of fibrous tissue. The cytotoxicity was tested by measuring the cell viability and using XTT. Analysis of chemical composition was performed for the purpose of determining the individual substances in the process fluids and their chemical stability. Qualitative analysis of the process fluids was performed using gas chromatography mass spectrometry (GC - MS).
\end{abstract}

Keywords: nanoparticles, silver, cytotoxicity, chemical composition

\section{INTRODUCTION}

Process fluids (hereinafter also referred to as "PF") are coolant or lubricant fluids used for metal cutting and woodworking. They transfer heat from the cut, reduce frictional resistance, remove chips, serve to increase the tool lifetime and improve the quality of the machined surface. Process fluids must be non-corrosive and wholesome. The use of a lubricant during the machining process reduces cutting forces (lubricating effect) and transfers heat from the surface (cooling effect). It can therefore be directly concluded that lubrication causes a reduction in the amount of residual stress and reduces the depth of the affected area. The basis of process fluids is water to which are added substances which increase the wettability and prevent corrosion. Process fluids must also have an appropriate $\mathrm{pH}$ (for steel $\mathrm{pH} \mathrm{8-9}$ is sufficient). If the $\mathrm{pH}$ is lower corrosion may appear on the workpiece. This type of process fluid is the most widespread and represents up to $80 \%$ of the total volume of process fluids used in machining. [1] An important factor affecting the lifetime of process fluids is their particulate contamination during the machining process. Apart from the organic impurities in PF a large amount of solid particles generated during cutting are released. The amount of 
these particles in the liquid depends primarily on the anti-adhesive and tribological properties of specific PF. [2] The use of nanoparticles is one possible way of eliminating the bacteria and improving the biological, chemical and technological stability of liquids. Suitable alternatives for the development of antimicrobial agents are synthesized nanoparticles of metals which are bactericidal (mainly nanoparticles based on silver). Nanoparticles with a size less than $100 \mathrm{~nm}$ have a large surface area and can interact more easily with biological materials. [3, 4] Several methods have been used and described in the past to prepare silver nanoparticles, including chemical reduction of silver ions in aqueous solutions [5-7], thermal decomposition in organic solvents, chemical and photoreduction in reverse micelles [8], and radiation chemical reduction [9].

\section{MATERIALS AND METHODS}

In this study four industrially used process fluids were tested to which silver nanoparticles were added. In the study they are marked as PF 1, PF 2, PF 3 and PF 4.

\section{The addition of nanoparticles to the solution of process fluids}

All of the process fluids were modified by the addition of silver nitrate $\left(\mathrm{AgNO}_{3}\right)$ and ascorbic acid $\left(\mathrm{C}_{6} \mathrm{H}_{8} \mathrm{O}_{6}\right)$. The ascorbic acid was chosen for the purpose of improving the antimicrobial and antioxidant activity and it is also able to reduce the metallic silver nanoparticles from the silver nitrate solution. Two variants of process fluids were prepared: with the addition of silver only or with the addition of silver and vitamin C. Reduction of silver nanoparticles from silver nitrate was carried out by using UV radiation. The image of nanoparticles after the UV reduction can be seen in Figure 1. UV irradiation was performed in a closed chamber using a high performance halogen metal vapour lamp with a combination of metal halides generating strong radiation in the UVB range $(280-315 \mathrm{~nm})$ and especially in the UVA range (315-380 $\mathrm{nm})$.

\section{Measurements of the chemical composition of process fluids}

The qualitative analysis was performed with concentrates of all process of the fluids using a static SPME-GC-MS with the help of sorption SPME fibres. This qualitative method is based on the detection of VOCs released into the vapour space above the sample of the process fluid on the surface of a thin layer of active phase SPME fibre, which leads to their concentration. Subsequently, the captured volatile analytes from the surface of the SPME fibre are thermally desorbed in the spraying member of the gas chromatograph and detected by mass spectrometry.

\section{Cytotoxicity test}

Human dermal fibroblasts (ATCC, No. PCS-201-012) were seeded onto 96-well plates at a density of $2 \times 10^{3}$ cells per well and cultured for 24 hours at $37{ }^{\circ} \mathrm{C}$ in a $5 \% \mathrm{CO}_{2}$ humidified incubator. The tested emulsions (stock solution $5 \%(\mathrm{v} / \mathrm{v})$ in $\left.\mathrm{H}_{2} \mathrm{O}\right)$ were diluted in complete culture medium to obtain the final concentrations: $0.05 \% ; 0.025 \% ; 0.005 \% ; 0.0025 \%$; $0.0005 \%$; $0.00025 \%$; $0.00005 \%$. 


\section{Viability}

A control (non-treated cells), positive control $\left(\mathrm{H}_{2} \mathrm{O}_{2}\right.$-treated cells) and solvent control $\left(\mathrm{ddH}_{2} \mathrm{O}\right.$-treated cells) were included in all of the experimental sets. The conditioned medium was replaced and the cells were exposed to the medium containing emulsions for 24 hours. The medium was then removed and the cells were rinsed with D-PBS and incubated for 30 minutes at RT in Hank's Balanced Salt Solution containing a fluorescent dye Hoechst 33342 at the final concentration of $0.5 \mu \mathrm{g} / \mathrm{ml}$, calcein-AM at the final concentration of $0.5 \mu \mathrm{M}$, and ethidium homodimer- 1 at the final concentration of $1 \mu \mathrm{M}$. Living cells were distinguished by the presence of intracellular esterase activity, determined by the enzymatic conversion of the nonfluorescent cell-permeant calcein-AM to the green fluorescent calcein well-retained within living cells. Dead cells were discriminated by staining with red-fluorescent ethidium homodimer-1 to indicate a loss of cellular membrane integrity. The total cell count was determined on the basis of cell nuclei stained with Hoechst 33342 dye. The cells were imaged by an automated microscope GE Healthcare's In Cell Analyzer 2000 with a $10 \times 0.45$ NA lens.

\section{XTT assay}

The cells were cultured in FBM supplemented with Fibroblast Growth Kit - Low Serum (ATTC, No. PCS-201-041). The cells were grown in a monolayer at $37{ }^{\circ} \mathrm{C}$ in $5 \% \mathrm{CO}_{2}$ atmosphere. The XTT reduction assay for cell survival assessment, a sensitive marker of mitochondrial activity, was used to evaluate the cytotoxicity of the provided emulsions on the human dermal fibroblast cell culture. The cells were seeded onto 96-well plates in the number of $8 \times 10^{3}$ cells per wall in $100 \mu \mathrm{L}$ of grow medium and cultured for 24 hours at $37^{\circ} \mathrm{C}$ in a $5 \%$ $\mathrm{CO}_{2}$ humidified incubator. A negative control (non-treated cells), positive control (mitomycin-treated cells) and solvent control ( $\mathrm{ddH}_{2} 0$-treated cells) were included in all of the experimental sets. The conditioned medium was replaced with the medium containing emulsions and the cells were incubated for another $24 \mathrm{~h}$. Subsequently, the XTT assay was prepared. The difference between the results was considered as statistically significant for $\mathrm{p}<0.05$. The results were expressed as the mean (viability-V) \pm standard deviation (SD).

\section{RESULTS AND DISCUSSION}

Reduction of silver nanoparticles resulted in a change in the colour of the tested process fluids. Figure 2 successively shows a) $5 \%$ solution of pure PF; b) $5 \%$ solution PF with $0.3 \mathrm{~g} / 1$ of $\mathrm{AgNO}_{3}$ and c) $5 \%$ solution of $\mathrm{PF}$ with the addition of $0.3 \mathrm{~g} / 1 \mathrm{AgNO}_{3}+0.1 \mathrm{~g} / 1 \mathrm{C}_{6} \mathrm{H}_{8} \mathrm{O}_{6}$. 


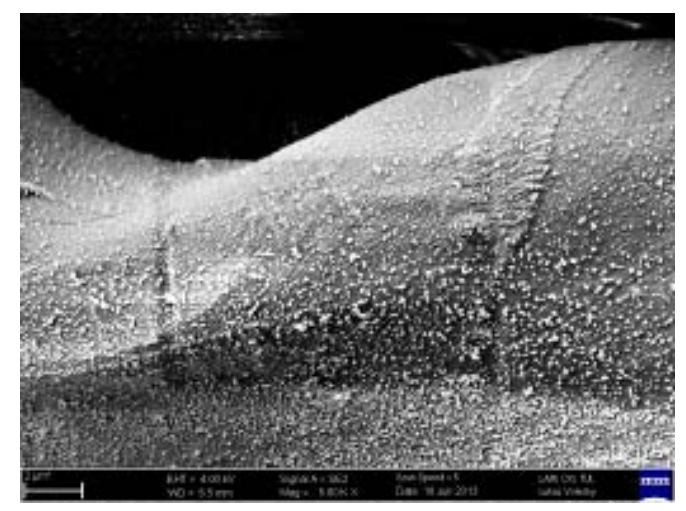

Fig. 1. Cotton fabric immersed in a solution of PF 2 with $\mathrm{AgNO}$, the reduction was subsequently performed by UV

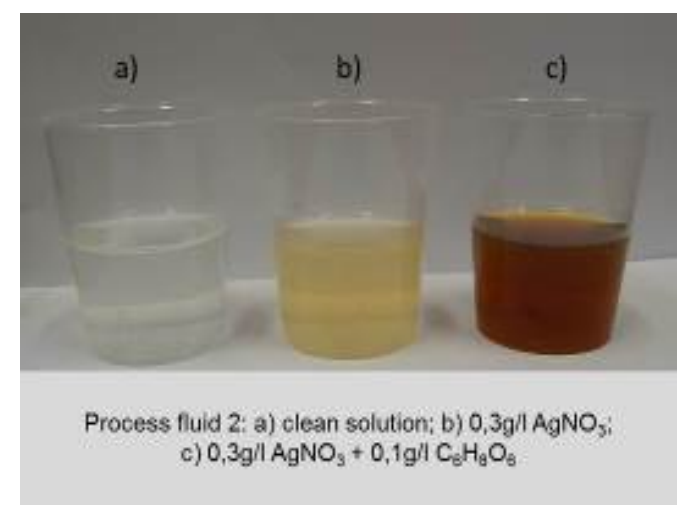

Fig. 2. Solutions of process fluid PF2

From the above figures it is evident that the reduction of the silver nanoparticles is more efficient in the case of a combination of UV reduction + vitamin C. Darkening of the liquids means a smaller size of the final nanoparticles.

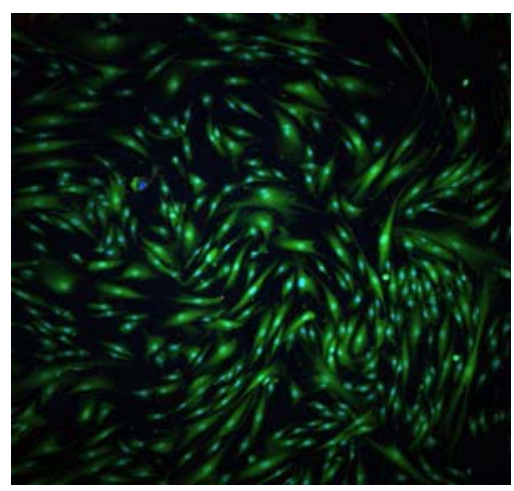

Fig. 3. Negative control

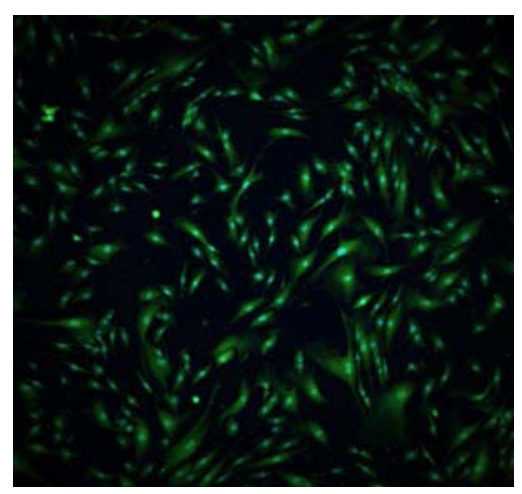

Fig. 4. PF 3 clean solution $0.0025 \%$

Figure 3 shows images of the negative control where the fibroblasts retained the green calcein in the cytoplasm and show normal morphology. As can be seen in Figure 4 the cells are viable because the green calcein is retained within the cytoplasm and they show the appropriate morphology. For all of the tested fluids the cytotoxicity was better in the case of lower concentrations of the measured liquids $(0.00005 \%)$. The selected process fluid was further 
tested for cytotoxicity after the addition of $0.3 \mathrm{~g} / 1 \mathrm{AgNO}_{3}$ and $0.1 \mathrm{~g} / 1$ ascorbic acid. Results of cell viability are shown in Tables 1 and 2.

Table 1. Viability of the process fluids

\begin{tabular}{|c|c|c|c|}
\hline \multicolumn{4}{|c|}{ Viability $[\%]^{*}$} \\
\hline PF 1 & PF 2 & PF 3 & PF 4 \\
\hline 90 & 92 & 80 & 96 \\
\hline
\end{tabular}

Table 2. PF 3 after the addition of NPS

\begin{tabular}{|c|c|}
\hline \multicolumn{2}{|c|}{ Viability [\%] ${ }^{*}$} \\
\hline PF 3 + AgNO $_{3}+\mathbf{C}$ & PF 3 $+\mathbf{A g N O}_{3}$ \\
\hline 91 & 83 \\
\hline
\end{tabular}

From the results below ( see Figure 5) it is also clear that the process fluid containing the silver nitrate and vitamin $C$ reached a higher degree of viability (more than 5-15\%) than in the case of clean PF 3 at all of the measured concentrations. The process fluid which contained only the silver nitrate achieved the same or slightly higher degree of viability for all measured concentrations.

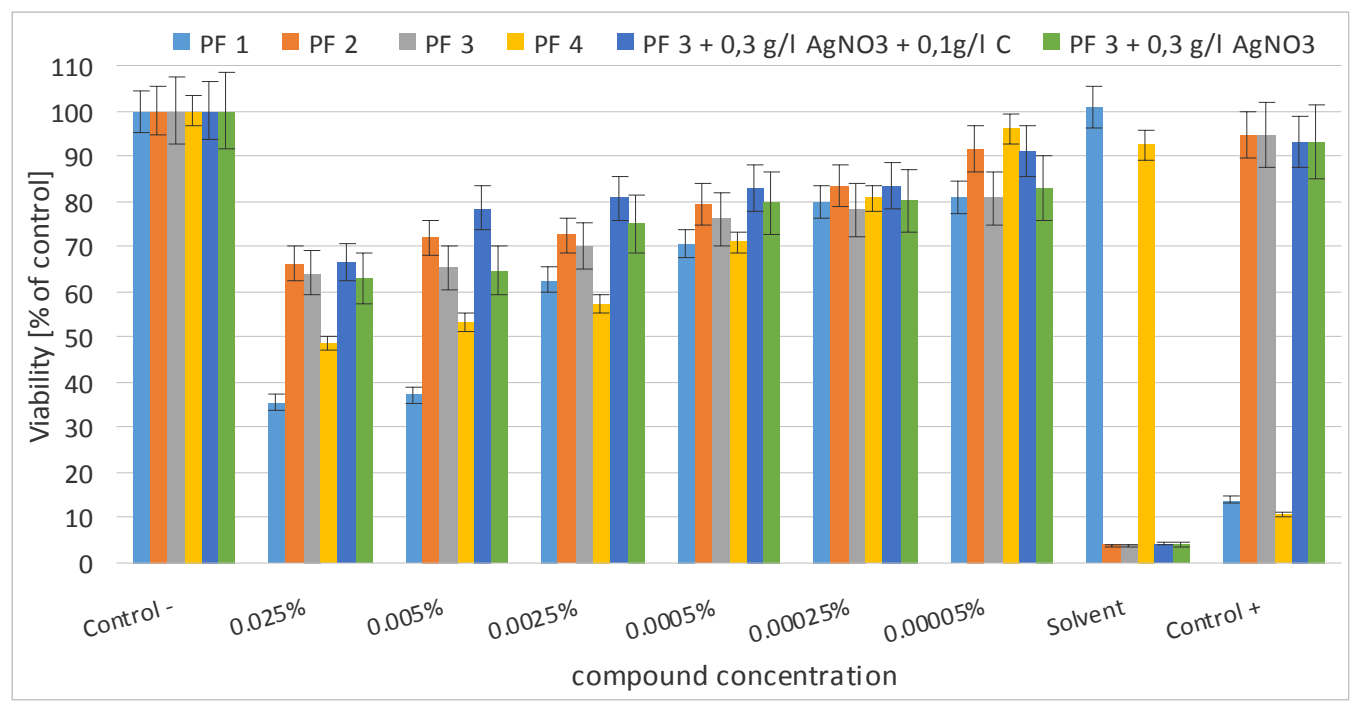

Fig. 5. The effect of emulsions on the human dermal fibroblast viability (XTT)

Figures 6 to 9 show the reconstructed chromatograms of analyzed steam spaces above the hot solutions of clean process fluids and process fluids after the addition of $\mathrm{AgNO}_{3}$ and ascorbic acid. The numbers above the peaks represent the chromatographic retention times (RT) of eluting substances expressed in minutes. 


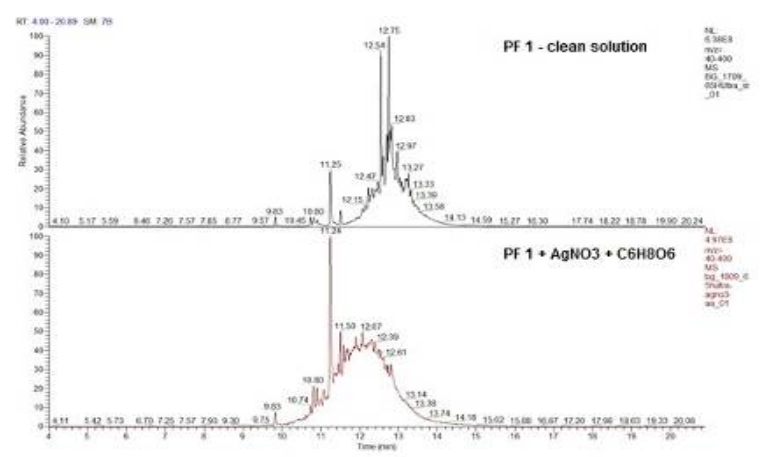

Fig. 6. Comparison of PF 1 solutions

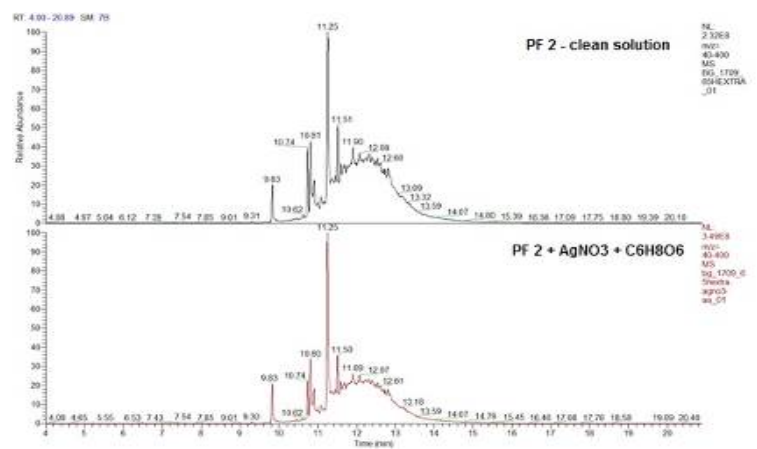

Fig. 7. Comparison of PF 2 solutions

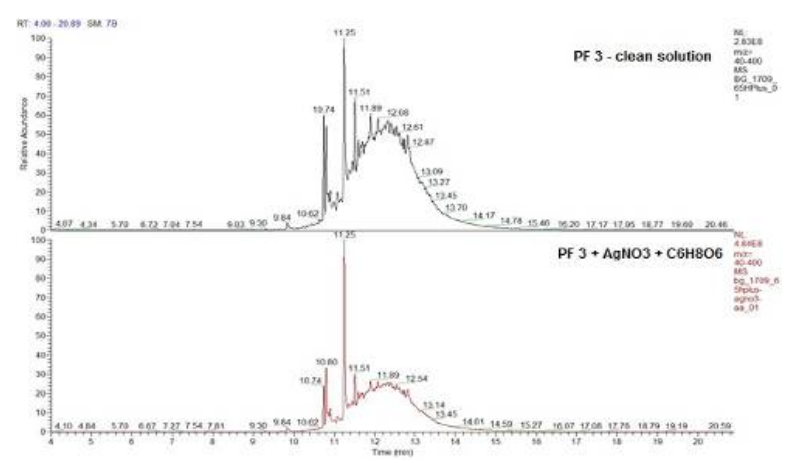

Fig. 8. Comparison of PF 3 solutions

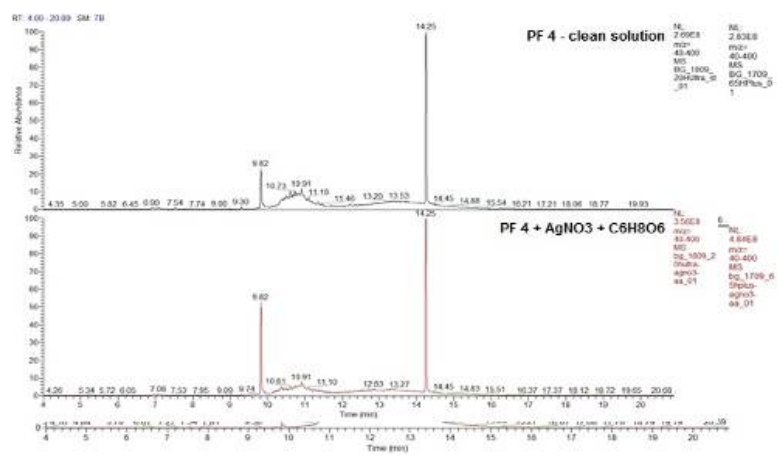

Fig. 9. Comparison of PF 4solutions 
From Figures 6 to 9 it is clear that after the addition of additives there was no significant change in the chemical composition of the PF solutions. In the case of sample PF 1; however, it seems that after the addition of silver nitrate and ascorbic acid there is a substantial change in the composition (loss of chromatographic peaks RT $12.54 \mathrm{~min}$ and $12.75 \mathrm{~min}$ ), but these compounds in the sample of PF 1 after the addition of silver nitrate and ascorbic acid were also identified but in a much lesser extent. The samples PF 1, PF 2 and PF 3 are formed mainly by oxygenated organic compound types of glycols and higher alcohols. Sample PF 4 is a mixture of different amines with one oxygen atom in the molecule.

\section{CONCLUSIONS}

The results show that all of the tested fluids were cytotoxic to fibroblasts. However, in the case of more diluted solutions the cytotoxicity was low and cell viability in all cases was over $80 \%$. The cytotoxicity of process fluids can therefore be reduced by their dilution with water or other neutral liquids. The cytotoxicity of samples after the addition of silver nitrate and vitamin $\mathrm{C}$ was not increased. The viability after the addition of only silver nitrate to the solution of the process fluid was on the same level as the values of the clean process fluids. The addition of vitamin $\mathrm{C}$ and silver nitrate into the process fluid was found to increase the cell viability of fibroblasts up to $15 \%$. On the basis of the results of the determination of the samples PF 1, PF 2 and PF 3 can be marked in terms of chemical composition as the same. These PF apparently differ only in their individual components.

\section{ACKNOWLEDGEMENTS}

The paper was supported in part by the project OP VaVpI „Innovative products and environmental technologies", registration number CZ.1.05/3.1.00/14.0306. The results of this project LO1201 were obtained through the financial support of the Ministry of Education, Youth and Sports in the framework of the targeted support of the "National Programme for Sustainability I" and the OPR\&DI project Centre for Nanomaterials, Advanced Technologies and Innovation CZ.1.05/2.1.00/01.0005.

\section{REFERENCES}

1. Dalik, P.: Vodou mísitelné chladicí kapaliny. In MM Průmyslové spektrum. 12/ 2005, č. 12. s. 62. Praha: SEND Předplatné s.r.o., 2005. ISSN 1212- 2572.

2. Holmberg, K., Matthews, K.: Coatings tribology: properties, mechanisms,techniques and applications in surface engineering. 2nd ed. Boston: Elsevier Science, c2009, xv, 560 p.

3. Nosonovski M., Rohatgi, P.: Biomimetics in materials science: self-healing, self- lubricating, and self-cleaning materials. New York, NY: Springer, c2012, xxvi, 415 p. Springer series in materials science, 152. ISBN 14-614-0925-X.

4. Čihalova, K., Chudobova, D., Kopel, P., Adam, V., Kizek, R.: Nanočástice kovů jako moderní nástroje pro potlačení růstu bakterií. Inovační podnikání \& transfer technologií, 1 (2014), 30 - 31 
5. Liz Marzan, L., Lado-Tourino, I.: Reduction and Stabilization of Silver Nanoparticles in Ethanol by Nonionic Surfactants. Langmuir 12 (1996), 3585-3589.

6. Duff, D., Baiker, D.: A new hydrosol of gold clusters. 1. Formation and particle size variation. Langmuir 9 (1993), 2301-2309.

7. Henglein, A.: Physicochemical properties of small metal particles in solution: "microelectrode" reactions, chemisorption, composite metal particles, and the atom-to-metal Transition. Journal of Phys. Chem. 97 (1993), 5457-5471.

8. Henglein, A.: Reduction of $\operatorname{Ag}(\mathrm{CN}) 2$ on silver and platinum colloidal nanoparticles. Langmuir 17 (2001), 2329-2333

9. Henglein, A.: Colloidal Silver Nanoparticles: Photochemical Preparation and Interaction with O2, CCl4, and Some Metal Ions. Chemistry of Materials 10 (1998), 444- 450. 